\title{
Identifikasi Kandungan Fitokimia Ekstrak Bunga Melati (Jasminum sambac (L.)ai) Komoditas Lokal yang Berpotensi Sebagai Antilarvasida
}

\author{
Nurul Hidayah1*, Anita Herawati1, Ahmad Habibi2 \\ 1Jurusan Promosi Kesehatan, Universitas Sari Mulia, Banjarmasin, Kalimantan Selatan \\ 2Program Studi Ilmu Keperawatan, Universitas Sari Mulia, Banjarmasin, Kalimantan Selatan \\ *hiragi_12@yahoo.com
}

DOI: https://doi.org/10.33859/dksm.v10i1.450

\begin{abstract}
Abstrak
Latar Belakang Masalah. Karakteristik tempat penampungan air dan parameter air di Kecamatan Martapura terbukti potensial untuk perkembangbiakan nyamuk A. aegypti. Masyarakat biasanya menggunakan antilarvasida kimia (temefos) untuk menangani masalah tersebut. Akan tetapi beberapa penelitian telah membuktikan adanya resistensi jentik terhadap temefos, sehingga perlu adanya antilarvasida alami. Salah satunya adalah bunga melati.

Tujuan Penelitian. Mengetahui kandungan fitokimia ekstrak bunga melati komoditas lokal yang berpotensi sebagai antilarvasida.

Metode Penelitian. Ekstraksi bunga melati dilakukann dengan metode maserasi menggunakan etanol. Uji metabolit sekunder yang dilakukan adalah uji alkaloid, flavonoid, saponin, steroid/terpenoid, dan tannin.

Hasil. Berdasarkan hasil uji metabolit sekunder diketahui bahwa ekstrak bunga melati komoditas local Kecamatan Martapura positif mengandung alkaloid, flavonoid, saponin, dan tannin.

Kesimpulan. Kandungan fitokimia yang terdapat pada ekstrak bunga melati komoditas lokal secara kajian literatur memiliki potensi sebagai antilarvasida dan perlu dibuktikan dengan penelitian lebih lanjut.
\end{abstract}

Kata Kunci: Bunga melati, metabolit sekunder, uji fitokimia 
Dinamika Kesehatan Jurnal Kebidanan dan Keperawatan Vol 10 No. 1 Juli 2019 ( ISSN: 2086-3454 EISSN: 2549-4058)

url: http://ojs.dinamikakesehatan.unism.ac.id DOI : https://doi.org/10.33859/dksm.v10il.450

Identifikasi Kandungan Fitokimia Ekstrak Bunga Melati (Jasminum sambac (L.)ai) Komoditas Lokal yang

Berpotensi Sebagai Antilarvasida

Identification of Phytochemical Content of Jasmine Flower Extract (Jasminum sambac (L.) ai) Local Commodities that Potential as Antilarvasida

\begin{abstract}
Background: The characteristics of water reservoirs and water parameters in Martapura District have proven potential for breeding A. aegypti mosquitoes. The community usually uses chemical antilarvasides (temefos) to deal with the problem. However, several studies have proven the existence of larvae resistance to temefos, so that natural antilarvasides are needed. One of them is jasmine flower.

Objective: To knowing the phytochemical content of jasmine flower extracts of local commodities that have the potential as antilarvasides.

Method: Jasmine flower extraction is done by maceration method using ethanol. Secondary metabolite tests performed were alkaloid, flavonoid, saponin, steroid / terpenoid, and tannin tests.

The results: Based on the results of the secondary metabolite test, it is known that the jasmine flower extract of the local commodity Martapura District positively contains alkaloids, flavonoids, saponins, and tannins.

Conclusion: Phytochemical content contained in jasmine flower extracts of local commodities by literature study has the potential as an antilarvaside and needs to be proven by further research.
\end{abstract}

Keywords: Jasmine flowers, secondary metabolites, phytochemical tests 


\section{Pendahuluan}

Kabupaten Banjar merupakan salah satu Kabupaten di wilayah Provinsi Kalimantan Selatan yang merupakan daerah endemis Demam Berdarah Dengue (DBD). Khususnya di Kecamatan Martapura. Penelitian Hidayah, Iskandar and Abidin (2017) diketahui bahwa sebagian besar masyarakat di Kecamatan Martapura memiliki karakteristik tempat perindukan nyamuk Aedes aegypti yang potensial yaitu berwarna gelap, terletak di luar rumah, tidak ada tutup, dan sumber air sumur. Karakteristik tersebut terbukti berhubungan dengan keberadaan jentik.

Selain itu, kondisi parameter air di Kecamatan Martapura, seperti suhu, salinitas, dan Dissolved Oxygen, terbukti secara signifikan lebih potensial sebagai tempat perkembangbiakan vector DBD yaitu nyamuk Aedes aegypti dibandingkan wilayah non endemis Hidayah dan Rahmawati (2019). Oleh karena itu, masyarakat biasanya menggunakan antilarvasida untuk mengatasi perkembangbiakan vector tersebut.

Pada umumnya antilarvasida yang digunakan adalah temefos (abate). Akan tetapi, beberapa penelitian menunjukan adanya resistensi temefos di beberapa negara di dunia, termasuk Indonesia (Yanti, Damar and Retno, 2010; Sordo and Salazar, 2015). Selain itu, penggunaan temefos selama waktu yang cukup lama dapat menyebabkan kerusakan DNA pada limfosit tubuh manusia (Sordo and Salazar, 2015).

Berdasarkan hal tersebut, perlu adanya antilarvasida alternatif yang sifatnya efektif dan memiliki dampak negatif yang minim, seperti penggunaan antilarvasida alami. Salah satu bahan alam yang dapat digunakan sebagai larvasida alami adalah bunga melati (Astriani and Widawati, 2016).

Melati merupakan salah satu komoditas bernilai ekonomi tinggi, kegunaannya tidak hanya sebagai tanaman hias pot dan taman, tetapi juga sebagai pengharum teh, bahan baku industri parfum, kosmetik, obat tradisional, bunga tabur pusara, penghias ruangan, dekorasi pelaminan, dan pelengkap dalam upacara adat (Ningsih and Pujawati, 2016).

Bunga melati merupakan salah satu komoditas lokal di Kecamatan Martapura Kabupaten Banjar. Hal ini dikarenakan masyarakat sepanjang Desa Tunggul Irang sampai Bincau dan Jinggah Habang dikenal sebagai pembudidaya bunga melati.

Disamping itu, pemerintah Provinsi Kalimantan Selatan telah mencanangkan Kabupaten Banjar menjadi sentra melati. Bunga melati sering dimanfaatkan oleh masyarakat dalam acara adat, tata rias, maupun obat-obatan (Ningsih and Pujawati, 2016). Akan tetapi masyarakat belum pernah menggunakan bunga melati sebagai antilarvasida. 
Dinamika Kesehatan Jurnal Kebidanan dan Keperawatan Vol 10 No. 1 Juli 2019 ( ISSN: 2086-3454 EISSN: 2549-4058)

url: http://ojs.dinamikakesehatan.unism.ac.id DOI : https://doi.org/10.33859/dksm.v10il.450

Identifikasi Kandungan Fitokimia Ekstrak Bunga Melati (Jasminum sambac (L.)ai) Komoditas Lokal yang

Berpotensi Sebagai Antilarvasida

Studi literatur yang dilakukan oleh Astriani and Widawati (2016), disimpulkan bahwa melati merupakan salah satu tanaman dengan efektifitas yang paling tinggi sebagai larvasida alami dibandingkan dengan 25 tanaman yang lainnya. Sebagai salah satu upaya membuktikan adanya potensi bunga melati sebagai antilarvasida maka perlu diketahui kandungan fotokimia dari ekstrak bunga melati tersebut.

\section{Metode}

\section{a. Tempat Penelitian}

Penelitian dilakukan di Laboratorium Mikrobiologi dan Bahan Alam Universitas Sari Mulia.

\section{b. Alat dan Bahan}

Peralatan yang digunakan dalam penelitian ini adalah gelas ukur, timbangan digitalkimia blender, gunting tanaman, pipet tetes, corong, petridish, botol, dan kertas saring.

Bahan-bahan yang digunakan dalam penelitian ini adalah bunga melati, aquades, etanol, asam sulfat, natrium hidroksida, asam klorida, kloroforn, reagen Mayer, reagen Wagner dan Besi (III) klorida.

\section{c. Prosedur Penelitian}

1. Ekstraksi

Ekstraksi dilakukan secara maserasi dengan menggunakan etanol. Sebanyak kurang lebih $500 \mathrm{~g}$ bunga melati yang telah diangin-anginkan hingga kering direndam dengan 1000 $\mathrm{mL}$ etanol, ditutup lalu disimpan di ruang gelap selama 1 minggu. Setelah itu, filtrate diambil dan residu dibuang (Ningsih, Zusfahair and Kartika, 2016).
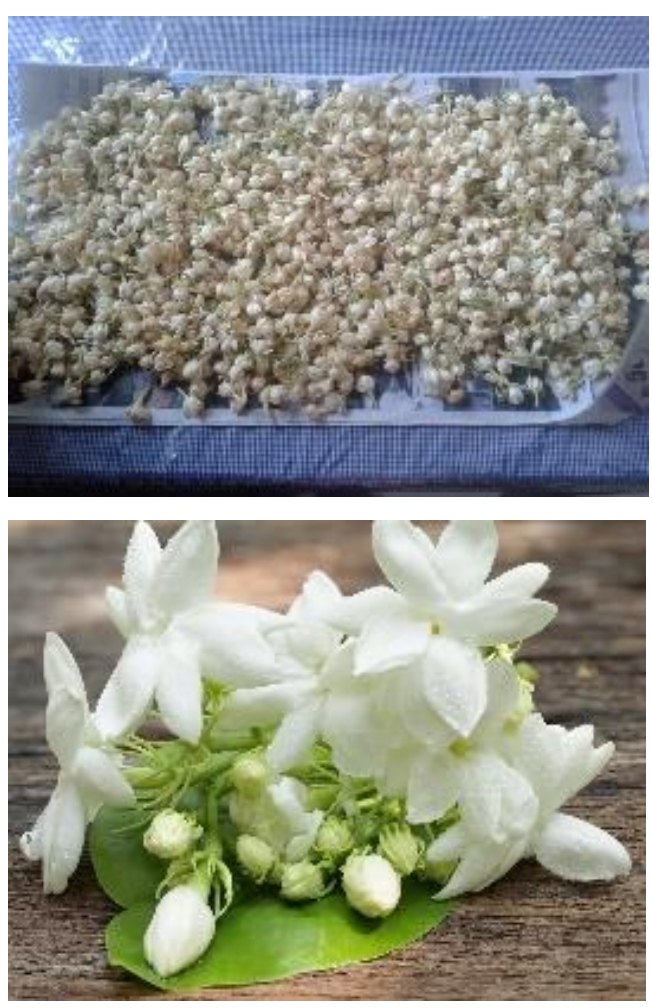

Gambar 1. Bunga melati (Jasminum $\operatorname{sambac}($ L.)aid)

2. Uji Alkaloid

Sampel ekstrak dilarutkan dalam $2 \mathrm{~mL}$ asam klorida, dipanaskan 5 menit, dan disaring. Filtrat yang diperoleh ditambah 2-3 tetes pereaksi Dragendorff. Adanya senyawa alkaloid ditunjukkan dengan endapan jingga (Ningsih, Zusfahair and Kartika, 2016). 
3. Uji Flavanoid

Sebanyak $2 \mathrm{~mL}$ sampel dilarutkan dalam $2 \mathrm{~mL}$ methanol, kemudian ditambahkan serbuk $\mathrm{Mg}$ dan $\mathrm{HCl}$ pekat sebanyak 5 tetes. Adanya senyawa flavonoid ditunjukkan dengan terbentuknya warna merah atau jingga (Ningsih, Zusfahair and Kartika, 2016).

4. Uji Saponin

Saponin dapat dideteksi dengan uji busa dalam air panas. Busa yang stabil selama 10 menit dan tidak hilang pada penambahan 1 tetes $\mathrm{HCl} 2$ $\mathrm{N}$ menunjukkan positif saponin (Syafitri, Bintang and Falah, 2014).

5. Uji Steroid/Terpenoid

Sebanyak $5 \mathrm{~mL}$ sampel dimasukkan ke dalam gelas kimia, kemudian ditambahkan kloroform dan diaduk. Selanjutnya ditambahkan pereaksi $\mathrm{H}_{2} \mathrm{SO}_{4}$ pekat. Apabila terbentuk warna merah menunjukkan adanya steroid/terpenoid (Agustina, Wiraningtyas and Bima, 2016).

6. Uji Tannin

Ekstrak bunga melati ditetesi gelatin $10 \%$. Dinyatakan positif mengandung tannin apabila membentuk endapan putih atau terjadi perubahan warna menjadi keruh (Masitoh, 2011).

\section{Hasil dan Pembahasan}

Hasil uji metabolit sekunder ekstrak bunga melati dapat dilihat pada tabel 1 dan gambar 1. Hasil positif adalah pada senyawa flavonoid, tannin, alkaloid, dan saponin.

Tabel 1. Hasil uji metabolit sekunder ekstrak bunga melati (Jasminum sambac (L).ai) komoditas lokal

\begin{tabular}{cc}
\hline Jenis Senyawa & Hasil $(+/-)$ \\
Flavonoid & + \\
\hline Tannin & + \\
\hline Alkaloid & + \\
\hline Steroid/Terpenoid & - \\
\hline Saponin & + \\
\hline
\end{tabular}

Keterangan:

$(+)=$ mengandung senyawa metabolit sekunder

$(-)=$ tidak mengandung senyawa metabolit sekunder 
Dinamika Kesehatan Jurnal Kebidanan dan Keperawatan Vol 10 No. 1 Juli 2019 ( ISSN: 2086-3454 EISSN: 2549-4058)

url: http://ojs.dinamikakesehatan.unism.ac.id DOI : https://doi.org/10.33859/dksm.v10il.450

Identifikasi Kandungan Fitokimia Ekstrak Bunga Melati (Jasminum sambac (L.)ai) Komoditas Lokal yang

Berpotensi Sebagai Antilarvasida

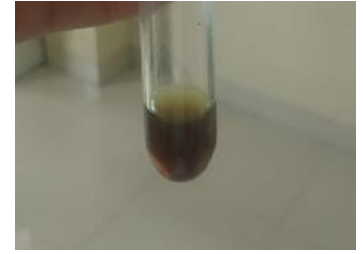

(a)

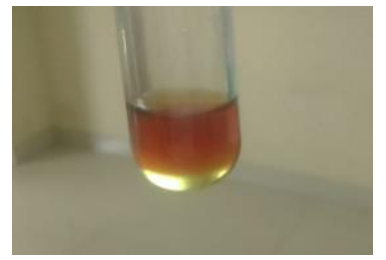

(c)

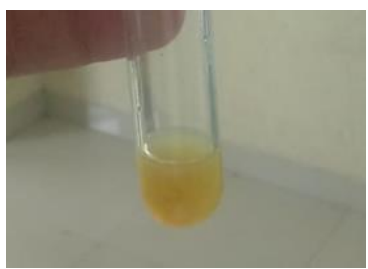

(b)

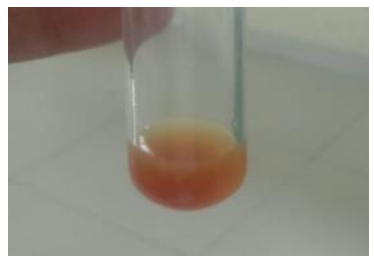

(d)
Gambar 2. Hasil uji saponin (a), tannin (b), flavonoid (c), dan alkaloid (d) ekstrak bunga melati (Jasminum sambac (L.)aid).

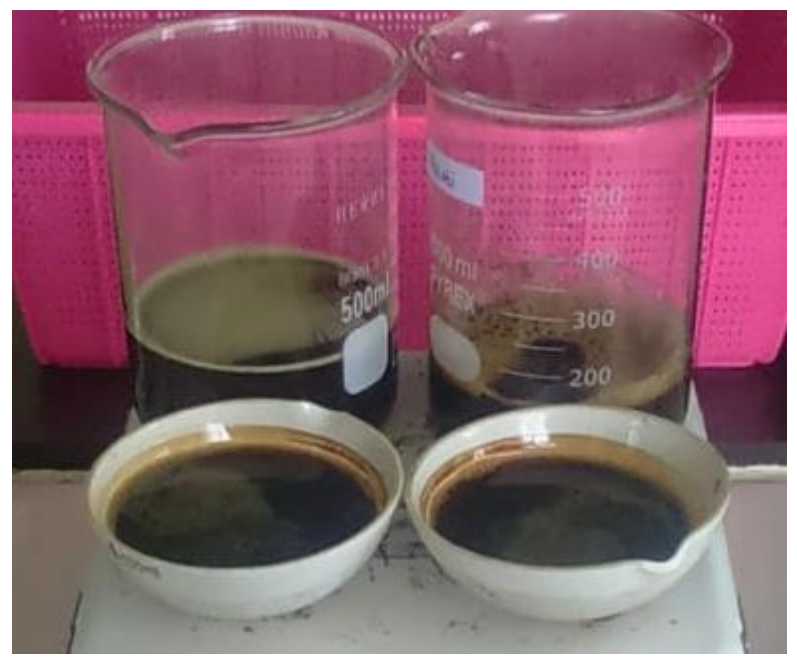

Gambar 3. Ekstrak bunga melati (Jasminum $\operatorname{sambac}(L) a i$.$) .$

\section{Pembahasan}

Karakter larutan yang dihasilkan dari ekstrak tanaman tergantung dari senyawa metabolit sekunder yang dikandung oleh tanaman tersebut (Oktari, Fitmawati and Sofiyanti, 2014).
Menurut Suryanto dan Mehantouw (2009) dalam Oktari, Fitmawati and Sofiyanti (2014), tannin dapat menyebabkan karakter larutan berwarna coklat sehingga pada ekstrak larutan cenderung kecoklatan. Aroma larutan yang berbau harus mengindikasikan bahwa larutan tersebut mengandung flavonoid.

Pada gambar 3 terlihat ekstrak bunga melati berwarna cokelat gelap dan masih tercium berbau harum. Hal ini dikarenakan indikasi keberadaan metabolit sekunder yang terdapat pada bunga melati. Terbukti hasil uji metabolit sekunder menunjukkan bahwa ekstrak bunga melati postif mengandung tannin dan flavonoid.

Selain positif mengandung flavonoid dan tannin, ekstrak bunga melati juga terbukti positif mengandung saponin. Hasil penelitian Jawale (2014) didapat bahwa dari 4 jenis tanaman yang berbeda, yang paling efektif untuk membunuh jentik nyamuk adalah tanaman yang mengandung alkaloid dan saponin.

Senyawa alkaloid dapat digunakan sebagai antilarvasida yang cara kerjanya mirip temephos (abate). Apabila senyawa alkaloid dan flavonoid masuk ke dalam tubuh larva maka alat pencernaannya akan terganggu (Susanto and Setiyorini, 2017).

Selain itu, senyawa alkaloid dan flavonoid dapat menghambat reseptor perasa pada daerah mulut larva. Hal ini mengakibatkan larva tidak mendapatkan 
stimulus rasa sehingga tidak mampu mengenali makanannya dan akhirnya larva mati kelaparan (Susanto and Setiyorini, 2017).

\section{Kesimpulan}

Berdasarkan hal tersebut, disimpulkan bahwa senyawa-senyawa metabolit sekunder yang positif terkandung di dalam ekstrak bunga melati (flavonoid, alkaloid, saponin, dan tannin) berpotensi sebagai antilarvasida nyamuk Aedes aegypti.

\section{Ucapan Terimakasih}

Penelitian ini didanai oleh Kementerian Riset, Teknologi, dan Pendidikan Tinggi untuk hibah skem Penelitian Dosen Pemula pendanaan tahun 2019.

\section{Daftar Pustaka}

Agustina, S., Wiraningtyas, A. and Bima, K. (2016) 'Skrining fitokimia tanaman obat di kabupaten bima', 4, pp. 71-76.

Astriani, Y. and Widawati, M. (2016) 'Potensi Tanaman di Indonesia Sebagai Larvasida Alami Untuk Aedes aegypti Potential Plant In Indonesia As Natural Larvicides for Aedes aegypti', 8(2), pp. 37-46.

Hidayah, N., Iskandar, I. and Abidin, Z. (2017) 'Prevention of Dengue
Hemorrhagic Fever (DHF) Associated with the Aedes aegypti Larvae Presence based on the Type of Water Source', Journal of Tropical Life Science, 7(2), pp. 115-120. doi: 10.11594/jtls.07.02.05.

Hidayah, N. and Rahmawati, D. (2019) 'Biophysicochemical markers of the Aedes aegypti breeding water in endemic and non-endemic area', International Journal of Public Healths, 8(2), pp. 915. doi: 10.11591/ijphs.v8i2.18883.

Jawale, C. S. (2014) 'Larvicidal Activity of Some Saponin Containing Plants Against the Dengue Vector Aedes Aegypti.', 3(1), pp. 1-11.

Masitoh, S. (2011) Penapisan Fitokimia Ekstrak Etanol Beberapa Tanaman Obat Indonesia Serta Uji Aktivitas Anti Diabeter Melitus Melalui Penghambatan Enzim a-Glukosidase. Universitas Indonesia.

Ningsih, D. R., Zusfahair and Kartika, D. (2016) 'Identifikasi Senyawa Metabolit Sekunder Serta Uji Aktivitas Ekstrak Daun Sirsak Sebagai Antibakteri', Molekul, 11(1), pp. 101-111.

Ningsih, R. T. and Pujawati, E. D. (2016) 'Kajian pemanfaatan tumbuhan bunga pada masyarakat suku banjar di kecamatan karang intan kalimantan selatan', 13, pp. 37-45.

Oktari, T., Fitmawati and Sofiyanti, N. (2014) 
'Identifikasi dan Uji Fitokimia Ekstrak

Alami Tanaman Antiurolithiasis', JOM

FMIPA, 1(2), pp. 1-9.

Sordo, M. and Salazar, A. M. (2015)

'Cytostatic and genotoxic effect of temephos in human lymphocytes and Toxicology in Vitro Cytostatic and genotoxic effect of temephos in human lymphocytes and', TOXICOLOGY IN VITRO. Elsevier Ltd, 29(4), pp. 779786. doi: 10.1016/j.tiv.2015.02.008.

Susanto, A. and Setiyorini, E. (2017) 'Efektifitas kombinasi perasan daun sirih (Piper betle L.) dengan perangkap nyamuk terhadap kematian larva Aedes aegypti, upaya penurunan penderita DBD di Desa Jogoroto Kabupaten Jombang', Prosiding Seminar Nasional, 1, pp. 302-309.

Syafitri, N. E., Bintang, M. and Falah, S. (2014) 'Kandungan Fitokimia , Total Fenol, dan Total Flavonoid Ekstrak Buah Herendong (Melastoma affine D. Don)', Current Biochemistry, 1(3), pp. $105-115$.

Yanti, A. O., Damar, T. and Retno, H. (2010) 'Status Resistensi Vektor Demam Berdarah Dengue (Aedes aegypti) di Kecamatan Sidorejo Kota Salatiga Terhadap Temephos (Organofosfat)', Jurnal Vektora, IV(1), pp. 9-21. 